\title{
Differences of The Number of Maternal References in Semarang Public Health Center Based on MEOWS Scoring System
}

\author{
Aji Patriajati*, Soerjo Hadijono
}

Department of Obstetrics and Gynecology, Faculty of Medicine University of Diponegoro, dr. Kariadi General Hospital, Indonesia

Keywords:

High-risk pregnancy

$M M R$

MEOWS

Public Health Center

Referral

Poedji Rochjati Score Card

*) Correspondence to: ajimaria2005@gmail.com

Article history:

Received 01-06-2021

Accepted 01-11-2021

Availableonline10-12-2021

\begin{abstract}
Background: The maternal mortality rate (MMR) in Semarang is the secondhighest in Central Java with 121.5 per 100,000 live births. The early warning system with Early Warning Score and Maternal Emergency Early Warning System (PDKM) still has various shortcomings to reduce MMR.

Objective: This study aims to prove the effectiveness of the application of the PDKM in the form of Modified Early Obstetric Warning System (MEOWS) as an assessment of the risk of pregnancy in primary health facilities to reduce MMR in Semarang.

Methods: The study was conducted on all pregnant women who admitted to Tlogosari Wetan, Tlogosari Kulon, Bandarharjo, and Bangetayu public health center in Semarang and were willing to participate in the study and were referred to government hospitals using national health assurance (BPJS). Sampling was obtained by cluster random sampling and divided into intervention and control groups. The study used a pre-post test control group design method by comparing the use of the MEOWS and the Poedji Rochjati Score Card (PRSC) to the number of Public Health Center referrals in Semarang. The data obtained would be analysed statistically with the bivariate test, Mann-Whitney difference test, relative risk reduction (RRR), and absolute risk reduction (ARR).

Results: The results showed that 21 of $43(48.8 \%)$ patients were admitted to the control group and 26 of $36(72.2 \%)$ patients were admitted to the intervention group. Mann-Whitney test performed on the number of referrals after the intervention within 3 months showed significant results $(\mathrm{p}=0.033$; $\mathrm{p}<0.05)$. There was an increase in the number of maternal referrals at the Public Health Center in Semarang after the implementation of the MEOWS score by 1.48 times compared to using the PRSC (RR: $1.48 ; 95 \%$ CI: $1.02-2.13$ ).
\end{abstract}

Conclusion: The use of the MEOWS score could increase the awareness of potential referrals and was associated with complications in patients.

DIMJ, 2021, 2(2), 54-62 DOI: https://doi.org/10.14710/dimj.v2i2.11120

\section{Introduction}

Maternal Mortality Rate (MMR) is one of the parameters of national public health status. MMR represents the number of maternal deaths during a given time period per 100,000 live births during the same time period. The Maternal Mortality Rate in Indonesia is still below the Millennium Development Goals (MDGs) target, as it is expected a decrease of MMR by three-quarters in 2015 . Accordingly, Indonesia is targeted to lower MMR births from 305 deaths per 100.000 live births to 102 per 100.000 live in 2015.,2

The MMR in Semarang is the second-highest in Central Java Province in 2016, with 32 cases out of
26,337 live births or equals to 121.5 per 100,000 live births. ${ }^{3}$ In 2017, Semarang Public Health Service has reported an MMR of 83.3 per 100,000 live births. ${ }^{4}$

The high rate of maternal mortality in Indonesia is related to the high risks of pregnancy. Various risk factors that lead to poor pregnancy outcomes involve socioeconomic conditions, medical conditions, including antepartum and intrapartum-related pregnancy problems. Mortality from high-risk pregnancies can be diminished through close care and monitoring. ${ }^{5}$ Early Warning Score (EWS) has been proposed as a tool to reduce pregnancy morbidity and mortality from early warning signs, but there has not been much statistical analysis of its clinical outcome. ${ }^{6}$ 
Confidential Enquiry Maternal and Child Health have recommended the implementation of the Modified Early Obstetric Warning System (MEOWS) tool in clinical practice since 2007. ${ }^{7}$ Emergency early warning system which had been statistically proven can be used as a pregnancy screening tool. ${ }^{8-10}$

In Indonesia, we used Poedji Rochjati Score Card (PRSC) as a maternal emergency early warning system (PDKM), however the physiological assessment in pregnant women at each visit could not be examined using this tool.

The purpose of this study is to prove the application of the PDKM in the form of Modified Early Obstetric Warning System (MEOWS) as an assessment tool of the pregnancy risks in primary health care to reduce the MMR rate in Semarang.

\section{Literature Review \\ Maternal Mortality Rate}

During pregnancy, problems could arise from the pregnancy itself or external factors, such as anemia, infectious diseases or malignancy, which could increase the risk of complications in pregnancy, morbidity and mortality of pregnant women. MMR is one of the parameters in the public health status, representing the number of maternal deaths per 100,000 live births. High number of MMR was found in six provinces, including North Sumatra, Banten, West Java, Central Java, East Java and South Sulawesi with $52.6 \%$ of the total maternal mortality incidents in Indonesia. ${ }^{1-3}$

According to Semarang's health profile in 2016, the number of maternal deaths had reached 32 cases out of 26,337 live births or equivalent to 121.5 per 100,000 live births. The most frequent cause of maternal deaths in Semarang was disease (51\%), severe preeclampsia $(21 \%)$, bleeding $(12 \%)$, others $(9.4 \%)$, and sepsis $(6 \%){ }^{3}$

\section{Pregnancy Morbidity}

Obstetric morbidity is a morbidity in a pregnant woman, which could arise from the condition of her pregnancy or its management, but not as a result of an accident or a specific incident. Direct obstetric incidence is the biggest cause of severe maternal morbidity and maternal mortality (80\%) in developing countries. ${ }^{11}$ Severe morbidity is an unexpected outcome during the delivery process that holds consequences towards women's health, both on short and also long term. Scoring for screening is recently being developed as an effort to detect morbidity at early pregnancy. ${ }^{12}$

The highest morbidity in pregnancy was bleeding (43\%), hypertensive disorders in pregnancy (31\%) and suspected infection (20\%). The most common triggers included high blood pressure $(42 \%)$, tachycardia (28\%), and low blood pressure $(18 \%)$. On the contrary, temperature, respiratory rate, and oxygen saturation were the least common trigger parameters $\left(6 \%, 4 \%\right.$, and $2 \%$, respectively). ${ }^{13}$

\section{High-risk Pregnancy and Pregnancy Complication}

A high-risk pregnancy is defined as a period in which the mother, fetus, or neonate has a higher risk of death, disability, or abnormality compared to normal. Conditions considered as high-risk pregnancies were: preeclampsia, eclampsia, antepartum bleeding, infections during pregnancy, a history of chronic disease (diabetes mellitus, hypertension, heart disease), a history of problems in previous pregnancies (abortion and stillbirth), multiple pregnancies, maternal age under 18 or 35 years, 4 or more pregnancies, and a less than 1-year gap between the current and the previous pregnancy. ${ }^{14}$ Complication in pregnancy is an acute condition, both antepartum at a gestational age of 28 , $32,34,36,38$ and 40 weeks or postpartum, which might cause maternal death. ${ }^{15}$

The diagnosis of preeclampsia is based on the presence of specific hypertension due to pregnancy, along with other organ system dysfunction at the age of 20 weeks of pregnancy. It is marked by an increase in systolic blood pressure of at least $140 \mathrm{mmHg}$ or diastolic blood pressure of at least $90 \mathrm{mmHg}$ with proteinuria (more than $300 \mathrm{mg}$ in 24 hours). Eclampsia is a complication of preeclampsia which correlates with the presence of seizures. ${ }^{15}$

Antepartum bleeding is a bleeding during pregnancy of more than 28 weeks, which generates from the placenta or non-placenta. The most common causes are placenta previa, placental abruption and vasa previa. Delay in treatment can result in maternal and fetal death. ${ }^{15}$

Sepsis is the most common cause of infectious morbidity and mortality worldwide and has an impact on maternal mortality or postpartum mortality. The incidence of sepsis in pregnant women is associated with infections such as urinary tract infections, chorioamnionitis, endometritis, wound infections, and septic abortion. The causes of non-obstetric sepsis in pregnant women include malaria, HIV, and pneumonia. ${ }^{15}$

\section{Maternal Emergency Early Warning System MEWT}

Maternal Early Warning Trigger (MEWT) has been shown to significantly reduce severe maternal morbidity recommended by The Joint Commission, the National Partnership in Women's Health, and others. The MEWT tool identifies four major causes of maternal morbidity, namely sepsis, cardiovascular 
dysfunction, preeclampsia-severe hypertension, and bleeding. These four obstetric cases were the main cause of admission of maternal patients to the ICU and had a high rate of severe maternal morbidity. ${ }^{16,17}$ MEOWS

The Modified Early Obstetric Warning System (MEOWS) was approved by the Confidential Inquiry into Maternal and Child Health (CEMACH). ${ }^{18}$ The MEOWS parameters were made by distinguishing individual early warning indicators for adults and pregnant women. The MEOWS score contained temperature, systolic blood pressure, diastolic blood pressure, pulse, respiratory rate, degree of consciousness (AVPU), and urine output. It is expected that this early warning could overcome the patient's condition earlier so that prevention and management efforts could be given to prevent the condition from worsening. ${ }^{5,13}$ The MEOWS chart is used in the postpartum period up to six weeks after delivery. It is because the physiological changes during pregnancy have returned to normal and most pregnancy disorders have resolved within this time period. ${ }^{19}$

The MEOWS tool recommends the assessment and monitoring of patients with two moderate abnormal parameters (yellow mark) or one severe abnormal parameter (red mark). ${ }^{7}$

Vital sign monitoring is done twice a day or every 12 hours and is done pre and postpartum. If the score is more than 3 , then the monitoring needs to be repeated every 30-50 minutes and a warning is made to the midwife in charge. If the score continues to be more than 3 , the midwife must contact the doctor immediately. ${ }^{13}$

\section{Poedji Rochjati Score Card}

In Indonesia, The Poedji Rochjati Score Card (PRSC) is used by classifying the risk of pregnancy into 3 groups: risk factor group I (potential for obstetric distress with a score of 1-10), risk factor group II (obstetric distress with a score of 11-18), and risk factor group III (obstetric emergency with a score of 19-20). Referral to the hospital is done if the score is $\geq 12$. $^{15}$

High-risk factors can be abbreviated as $4 \mathrm{~T}$, too young, too old, too close, too many. Too young means pregnancy at the age of less than 20 years old. Too old means pregnancy at the age of more than 35 years old. Too close means that the range between the current pregnancy and the previous pregnancy is less than 1 year. Too much means a woman with more than 4 pregnancies. ${ }^{20}$

\section{Methods}

This study used a pre-post test control group design with a population of all pregnant women in Semarang. The sample of this study was all pregnant women admitted to the Tlogosari Wetan Public Health Center, Tlogosari Kulon Public Health Center, Bandarharjo Public Health Center, and Bangetayu Public Health Center in Semarang who met the inclusion criteria, including agreeing to participate in the research, and those who were referred to the hospital using national health insurance (BPJS). Pregnant women who were not willing to attend administrative records, antenatal care, and management of pregnant women at the Public Health Center, and had not completed medical records were excluded from the study. During the process, the subject can withdraw from the research at any time for some reason. Sampling was obtained by cluster random sampling in 4 Public Health Centers in Semarang and divided into 2 exposed groups and 2 non-exposed groups. All research subjects were kept anonymous.

Public Health Center referrals in Semarang was determined as the dependent variable. Maternal Early Obstetric Warning Score (MEOWS) and Poedji Rochjati Score Card (PRSC) were determined as independent variables whereas Gravidity, Body Mass Index were determined as confounding variables.

Data analysis was carried out after completeness and validity of the data were checked. Furthermore, descriptive analysis and computerized statistics were performed using SPSS version 26 software. The analysis performed included bivariate analysis, Mann Whitney difference test, Relative Risk Reduction (RRR), and Absolute Risk Reduction (ARR).

\section{Results}

The study was conducted at 4 Public Health Centers in Semarang with a demographic sample shown in Table 1. Bangetayu Public Health Center and Tlogosari Public Kulon Health Center were defined as the intervention group, while the control group was conducted at Bandarharjo Public Health Center and Tlogosari Public Wetan Health Center. The referral characteristics of all groups 3 months prior to intervention are shown in Table 2 and detailed for each public health center in Table 3. 
Table 1. Demographic characteristics of the study sample

\begin{tabular}{lcccccccc}
\hline \multicolumn{1}{c}{ PHC } & $\begin{array}{c}\text { KK } \\
\text { Number } \\
\text { of } \\
\text { families) }\end{array}$ & $\begin{array}{c}\text { Region } \\
\text { width } \\
\left(\mathrm{Km}^{3}\right)\end{array}$ & $\begin{array}{c}\text { Total } \\
\text { population }\end{array}$ & Villages & $\begin{array}{c}\text { General } \\
\text { practitioners }\end{array}$ & Midwife & $\begin{array}{c}\text { Nurse } \\
\text { healthrated } \\
\text { center/mother } \\
\text { and child } \\
\text { health }\end{array}$ \\
\hline $\begin{array}{l}\text { Tlogo sari } \\
\text { Kulon }\end{array}$ & 21.816 & 19 & 84.598 & 4 & 6 & 8 & 16 & 76 \\
Tlogo sari & 32.036 & 29 & 100.817 & 8 & 5 & 7 & 7 & 88 \\
Wetan & & & & & & & & \\
Bangetayu & 21.987 & 12 & 74.203 & 6 & 5 & 12 & 11 & 59 \\
Bandarharjo & 22.179 & 8 & 112.693 & 4 & 5 & 5 & 10 & 50 \\
\hline
\end{tabular}

Table 2. Referral characteristics of control and intervention group in 3 months prior to intervention

\begin{tabular}{|c|c|c|c|c|c|}
\hline \multirow[b]{2}{*}{ Groups } & \multirow{2}{*}{$\begin{array}{c}\text { The } \\
\text { number of } \\
\text { patients } \\
\text { administe } \\
\text { red }\end{array}$} & \multicolumn{2}{|c|}{ Referred } & \multicolumn{2}{|c|}{$\begin{array}{c}\text { Not } \\
\text { Referred }\end{array}$} \\
\hline & & $\mathrm{n}$ & $\%$ & $\mathrm{n}$ & $\%$ \\
\hline $\begin{array}{l}\text { Control } \\
\text { groups }\end{array}$ & 25 & 15 & 60.0 & 10 & 40.0 \\
\hline $\begin{array}{l}\text { Interventio } \\
\mathrm{n} \text { groups }\end{array}$ & 28 & 15 & 53.6 & 13 & 35.7 \\
\hline Total & 53 & 30 & 56.6 & 23 & 43.4 \\
\hline
\end{tabular}

The referral characteristics of all groups in 3 months prior to intervention based on PRSC score are shown in Table 4 and the referral characteristics of all groups within 3 months after intervention are shown in Table 5 and detailed for each Public Health Center in Table 6. The characteristics of the intervention group within 3 months of intervention based on the MEOWS are shown in Table 7 and Table 8.

Table 3. Reference characteristics of each public health center in the 3 months prior to intervention

\begin{tabular}{|c|c|c|c|}
\hline Groups & $\begin{array}{c}\text { Number } \\
\text { of patients } \\
\text { administe } \\
\text { red } \\
\end{array}$ & $\begin{array}{c}\text { Referr } \\
\text { ed }\end{array}$ & $\begin{array}{c}\text { Not } \\
\text { referred }\end{array}$ \\
\hline $\begin{array}{l}\text { Bandarharjo } \\
\text { Public Health } \\
\text { Center* }\end{array}$ & 13 & $\begin{array}{c}9 \\
(69 \%)\end{array}$ & $4(31 \%)$ \\
\hline $\begin{array}{l}\text { Tlogosari Wetan } \\
\text { Public Health } \\
\text { Center* }\end{array}$ & 12 & $\begin{array}{c}6 \\
(50 \%)\end{array}$ & $6(50 \%)$ \\
\hline $\begin{array}{l}\text { Bangetayu Public } \\
\text { Health Center\# }\end{array}$ & 14 & $\begin{array}{c}8 \\
(57 \%)\end{array}$ & $6(43 \%)$ \\
\hline $\begin{array}{l}\text { Tlogosari Kulon } \\
\text { Public Health } \\
\text { Center }^{\#}\end{array}$ & 14 & $\begin{array}{c}7 \\
(50 \%)\end{array}$ & $7(50 \%)$ \\
\hline Total & 53 & $\begin{array}{c}30 \\
(56 \%)\end{array}$ & $23(44 \%)$ \\
\hline
\end{tabular}

Table 4. Referral criteria for control and intervention groups in 3 months prior to intervention based on PRSC Score

\begin{tabular}{|c|c|c|c|}
\hline Groups & $\begin{array}{l}\text { Control } \\
\text { groups }\end{array}$ & $\begin{array}{c}\text { Intervention } \\
\text { groups }\end{array}$ & Total \\
\hline $\begin{array}{l}\text { Too young, the } \\
\text { first pregnancy } \\
\text { occurs at } \leq 16 \\
\text { years old age }\end{array}$ & 5 & 5 & 10 \\
\hline $\begin{array}{l}\text { Too old, the } \\
\text { first pregnancy } \\
\text { occurs at } \geq 35 \\
\text { years old age }\end{array}$ & 4 & 4 & 8 \\
\hline $\begin{array}{l}\text { Too late, the } \\
\text { first pregnancy } \\
\text { occurs after } \geq 4 \\
\text { years of } \\
\text { marriage }\end{array}$ & 3 & 3 & 6 \\
\hline $\begin{array}{l}\text { Too long (the } \\
\text { range of each } \\
\text { pregnancies is } \\
\geq 10 \text { years) }\end{array}$ & 3 & 4 & 7 \\
\hline $\begin{array}{l}\text { Too close (the } \\
\text { range of each } \\
\text { pregnancies is } \\
\leq 2 \text { years) }\end{array}$ & 2 & 4 & 6 \\
\hline $\begin{array}{l}\text { Too many, total } \\
\text { child of } \geq 4\end{array}$ & 1 & 3 & 4 \\
\hline $\begin{array}{l}\text { Too old, } \\
\text { mother's age at } \\
\text { pregnancy is } \\
\geq 35 \text { years old }\end{array}$ & 3 & 4 & 7 \\
\hline $\begin{array}{l}\text { Too short, } \\
\text { mother's height } \\
\text { is } \geq 145 \mathrm{~cm}\end{array}$ & 2 & 2 & 4 \\
\hline $\begin{array}{l}\text { History of } \\
\text { failure in } \\
\text { pregnancy }\end{array}$ & 3 & 3 & 6 \\
\hline $\begin{array}{l}\text { History of } \\
\text { labour using } \\
\text { forceps } \\
\text { extraction/vacu } \\
\text { um }\end{array}$ & 2 & 2 & 4 \\
\hline
\end{tabular}


Table 5. Referral characteristics of control and intervention groups within 3 months after intervention

\begin{tabular}{lccccc}
\hline & $\begin{array}{c}\text { The } \\
\text { Gumber of } \\
\text { patients }\end{array}$ & \multicolumn{2}{c}{ Referred } & \multicolumn{3}{c}{$\begin{array}{c}\text { Not } \\
\text { Referred } \\
\text { administe } \\
\text { red }\end{array}$} & $\mathrm{n}$ & $\%$ & $\mathrm{~N}$ & $\%$ \\
\hline $\begin{array}{l}\text { Control } \\
\text { groups } \\
\begin{array}{l}\text { Interventio } \\
\text { n groups }\end{array}\end{array}$ & 43 & 21 & 48.8 & 22 & 51.2 \\
\hline
\end{tabular}

Table 6. Referral characteristics of each public health center within 3 months of intervention

\begin{tabular}{lccc}
\hline \multicolumn{1}{c}{ Groups } & $\begin{array}{c}\text { Number } \\
\text { of patients } \\
\text { administe } \\
\text { red }\end{array}$ & Referred & $\begin{array}{c}\text { Not } \\
\text { referred }\end{array}$ \\
\hline $\begin{array}{l}\text { Bandarharjo } \\
\text { Public Health }\end{array}$ & 22 & $10(45 \%)$ & $12(55 \%)$ \\
$\begin{array}{l}\text { Center } \\
\text { Tlogosari }\end{array}$ & 21 & $11(52 \%)$ & $10(48 \%)$ \\
$\begin{array}{l}\text { Wetan Public } \\
\text { Health Center }\end{array}$ & & $13(76 \%)$ & $4(24 \%)$ \\
$\begin{array}{l}\text { Bangetayu } \\
\text { Public Health }\end{array}$ & 17 & & \\
$\begin{array}{l}\text { Center" } \\
\text { Tlogosari }\end{array}$ & & & \\
Kulon Public & 19 & & \\
Health Center & & & \\
\hline Total & & & \\
\hline${ }^{*}$ Control groups, ${ }^{*}$ Intervention groups \\
\hline
\end{tabular}

Table 7. Characteristics of the Bangetayu Public Health Center within 3 months after intervention based on the MEOWS

\begin{tabular}{lcccc}
\hline Groups & Score 0 & Score 1 & Score 2 & Skor 3 \\
\hline $\begin{array}{l}\text { Tempe- } \\
\text { rature }\end{array}$ & 15 & 0 & 0 & 0 \\
$\begin{array}{l}\text { Sistolic } \\
\text { blood } \\
\text { pressure }\end{array}$ & $(33.3 \%)$ & $(0 \%)$ & $(0 \%)$ & $(0 \%)$ \\
$\begin{array}{l}\text { Diastolic } \\
\text { blood }\end{array}$ & 5 & 5 & 5 & 0 \\
pressure & $(33.3 \%)$ & $(0 \%)$ & $(46.7 \%)$ & $(20 \%)$ \\
$\begin{array}{l}\text { Pulse } \\
\text { Respira- }\end{array}$ & 6 & 0 & 6 & $(0 \%)$ \\
tory & $140 \%)$ & $(0 \%)$ & $(40 \%)$ & $(20 \%)$ \\
$\begin{array}{l}\text { Rate } \\
\text { Consci- }\end{array}$ & $(93.3 \%)$ & $(6.7 \%)$ & $(0 \%)$ & $(0 \%)$ \\
$\begin{array}{l}\text { ousness } \\
\text { (AVPU) }\end{array}$ & $(100 \%)$ & $(0 \%)$ & $(0 \%)$ & $(0 \%)$ \\
$\begin{array}{l}\text { Oxygen } \\
\text { saturati- }\end{array}$ & 15 & 0 & 0 & 0 \\
on & $(100 \%)$ & $(0 \%)$ & $(0 \%)$ & $(0 \%)$ \\
\hline
\end{tabular}

Table 8. Characteristics of the Tlogosari Kulon Public Health Center within 3 months after intervention based on the MEOWS

\begin{tabular}{lcccc}
\hline Groups & Score 0 & Score 1 & Score 2 & Skor 3 \\
\hline $\begin{array}{l}\text { Tempe- } \\
\text { rature }\end{array}$ & 15 & 0 & 0 & 0 \\
$\begin{array}{l}\text { Systolic } \\
\text { blood }\end{array}$ & $(100 \%)$ & $(0 \%)$ & $(0 \%)$ & $(0 \%)$ \\
pressure & & 1 & 4 & 7 \\
$\begin{array}{l}\text { Diastolic } \\
\text { blood }\end{array}$ & 3 & $(6.7 \%)$ & $(26.7 \%)$ & $(46.7 \%)$ \\
pressure & $(20 \%)$ & $(6.7 \%)$ & $(13.3 \%)$ & $(60 \%)$ \\
$\begin{array}{l}\text { Pulse } \\
\text { Respira- }\end{array}$ & 13 & $2(13.3$ & $0(0 \%)$ & $0(0 \%)$ \\
tory & $(86.7 \%)$ & $\%)$ & $0(0 \%)$ & $0(0 \%)$ \\
$\begin{array}{l}\text { Rate } \\
\text { Consci- }\end{array}$ & $14.3 \%)$ & $1(6.7 \%)$ & 0 & \\
$\begin{array}{l}\text { ousness } \\
\text { (AVPU) }\end{array}$ & $(100 \%)$ & $0(0 \%)$ & $0(0 \%)$ & $0(0 \%)$ \\
$\begin{array}{l}\text { Oxygen } \\
\text { saturati- } \\
\text { on }\end{array}$ & 15 & $0(0 \%)$ & $0(0 \%)$ & $0(0 \%)$ \\
\hline
\end{tabular}

There were no significant differences using the Mann-Whitney test between the intervention group and the control group in the first 3 months using PRSC as a guideline for referral ( $p$ value $=0.637, p$ $>0.05$ ) (Table 9). In addition, for the next 3 months, the intervention groups used the MEOWS while the control groups used PRSC as a referral guideline. There was a significant difference between the intervention and control groups ( $p$ value $=0.033, p$ $<0.05)$. The referral percentage was increased from $53.6 \%$ to $72.2 \%$ (an increase of $18.6 \%$ ) (Table 10 ).

Table 9. Mann-Whitney test between control and intervention groups in 3 months prior to intervention

\begin{tabular}{|c|c|c|c|c|}
\hline \multirow{2}{*}{ Groups } & \multirow{2}{*}{$\mathbf{n}$} & \multicolumn{2}{|c|}{ Referred } & \multirow{2}{*}{$\mathbf{P}$} \\
\hline & & Yes & No & \\
\hline $\begin{array}{l}\text { Control } \\
\text { groups }\end{array}$ & 25 & $\begin{array}{c}15 \\
(60 \%)\end{array}$ & $\begin{array}{c}10 \\
(40 \%)\end{array}$ & $0,637 *$ \\
\hline $\begin{array}{l}\text { Intervention } \\
\text { groups }\end{array}$ & 28 & $\begin{array}{c}15 \\
(53 \%)\end{array}$ & $\begin{array}{c}13 \\
(47 \%)\end{array}$ & \\
\hline *chi-square & & & & \\
\hline
\end{tabular}

Table 10. Mann-Whitney test between control and intervention groups in 3 months after intervention

\begin{tabular}{lcccc}
\hline \multirow{2}{*}{ Groups } & \multirow{n}{*}{$\mathbf{n}$} & Referred & \multirow{2}{*}{ No } & p \\
\hline Control & \multirow{2}{*}{43} & 21 & 22 & \multirow{2}{*}{$0,033^{*}$} \\
groups & & $(48 \%)$ & $(52 \%)$ & \\
$\begin{array}{l}\text { Intervention } \\
\text { groups }\end{array}$ & 36 & 26 & 10 & \\
*chi-square & & $(72 \%)$ & $(28 \%)$ & \\
\hline
\end{tabular}

The relative risk reduction (RRR) in this study was $47.0 \%$. It demonstrated that if the MEOWS scoring was not applied, it could reduce the referral 
rate by $47.0 \%$. Absolute risk reduction (ARR) is the difference in the incidence of referral failure between the intervention group (MEOWS) and the control group (PRSC). The ARR in this study was $23.4 \%$, indicating that there was an increase of $23.4 \%$ in referrals after the intervention using the MEOWS score compared to the control group (PRSC) (Table 11).

Table 11. Relative risk (RR) of the MEOWS application to the number of referrals

\begin{tabular}{lccc}
\hline \multirow{2}{*}{ Groups } & \multicolumn{2}{c}{ Referred Patient } & \multirow{2}{*}{ RR (95\% CI) } \\
& Yes & No & 1,48 \\
Control & 21 & 22 & \\
& $(48 \%)$ & $(52 \%)$ & $($ CI 95\%:1,02-2,13) \\
Intervention & 26 & 10 & \\
\multirow{2}{*}{ Total } & $(72 \%)$ & $(28 \%)$ & \\
& $\mathbf{4 7}$ & $\mathbf{3 2}$ & \\
\hline
\end{tabular}

There were no significant differences in confounding factors (BMI, gravidity) in both groups, showed by $p=0.694$ for BMI and $p=0.935$ for gravidity $(p>0.05)$. It could be concluded that the characteristics of the confounding factors in the two groups could be ruled out.

\section{Discussion}

This study aims to compare the number of maternal referrals between the use of PRSC and the number of referrals after the implementation of the MEOWS, since the comparison of outcomes from each emergency early warning system is inadequately available in Indonesia.

The initial referral indication criteria were based on the PRSC score, in which $56.6 \%$ of cases were referred. In accordance with the referral at the beginning of the intervention, cases of leg swelling and high blood pressure were the most common cases, followed by too young (pregnancy at 16 years old). In a study conducted in Surabaya using the PRSC score, it was found that the same facts were established as the most common cases in pregnancy. ${ }^{20}$

In this study, there was a significant increase of $18.6 \%$ in the number of referrals after the intervention compared to referrals prior to intervention (PRSC). Although there was no previous study which assessed the number of referrals to health facilities according to the patient's clinical condition, it had been found that the MEOWS could be used to detect emergencies from the very beginning to provide better improvement in final outcomes. ${ }^{10,21,22}$ Singh et al., stated that the MEOWS was an early warning system with good validation of results with a sensitivity of $86.4 \%$ and a specificity of $85.2 \%$.[10] A study in North Carolina in 2005 claimed that $93 \%$ of maternal deaths due to bleeding actually had a chance of being prevented by MEOWS. . $^{8,923}$

Widarta et al., at RSUD Dr. Sutomo Surabaya, reported that those who were diagnosed with severe preeclampsia and heart disease tended to be detected by the use of PRSC, but opposite result was obtained in postpartum haemorrhage (PPH) ${ }^{20}$ It was due to the period where severe preeclampsia and heart disease occurred during pregnancy while $\mathrm{PPH}$ occurred after the delivery, while the Maternal risk in PRSC was only carried out during the pregnancy. In pregnancy with no risk factors, preparation for transportation to the referral site will be disrupted due to no preparation..$^{20,24}$

This study found quite a number of cases of gestational hypertension and also severe preeclampsia, which could be detected by the MEOWS or PRSC. In a study conducted in Yogyakarta, it was found that patients with severe preeclampsia with a MEOWS score of 8 had a 3.34 times risk of being admitted to the ICU compared to patients with severe preeclampsia with a MEOWS score of $<8.33 . .^{25}$

All health workers should fill in the warning card, both PRSC and MEOWS, based on patient's history and physical examination results. However, Singh et al., stated that several variables in the MEOWS such as respiratory rate were very susceptible to human error. ${ }^{10}$ The same result was also reported by Widarta et al., a study in 109 pregnant women using PRSC to detect four late factors claimed that the higher the risk level of pregnant women, the more factors were found to be late in detecting danger signs. This might be due to the varying expertise of practitioners in primary health services or indeed the case required specialistic abilities, so that it might be necessary to have specialists to screen pregnant women at a certain period and gestational age. ${ }^{20}$ Periodic training is needed to increase the ability of medical practitioners in using the MEOWS and to enlighten the early danger signs in high-risk pregnant women. In several studies in which MEOWS was applied as an early warning system for maternal emergencies, high systolic blood pressure and oxygen saturation determined using arterial oximetry or pulse measurements were important predictors of ICU patient care and serious complications or death in women with preeclampsia. ${ }^{20.22,26}$

In this study, the application of the MEOWS score increased the referral rate by 1.48 times higher compared to the application of PRSC. The early warning system is potential to improve the quality of 
maternal services and reduce maternal mortality in limited health facilities through early referrals. ${ }^{10,13}$

This study showed that neglection of the MEOWS score resulted in a decrease of the referral rate according to the patient's clinical condition. Furthermore, intervention using the MEOWS resulted in an increase of the referral rate compared to application of PRSC only. Shield, et al., showed that the implementation of an early warning system could reduce maternal morbidity. ${ }^{26}$ Several previous studies had also proven that the implementation of an early warning system was beneficial in reducing the risk of complications and death in pregnancy with a prompt, appropriate, and effective treatment that could be taken immediately. $6,21,26,27$

The application of an early warning system with the MEOWS had been proven by several studies with high validity and a negative predictive value of $96.9 \%$ in predicting obstetric morbidity. ${ }^{10,21}$ Although as a screening tool, slight differences in sensitivity could be found in some local settings. ${ }^{8-}$ 10,22,28 Novel scientific evidence supported the suggestion that early warning parameters might be useful clinically for identifying patients who was potentially critical or at high-risk of death. Recently, no data had defined the optimal response to determine which maternal care to improve after warning signs appeared. ${ }^{8}$

In this study, environmental, social, and health insurance factors also influenced the decision of referrals. Another factor that affects referral was the patient's problem which was excluded from the criteria but still required referral, such as obstetric indications and fetal indications. In the future, it is necessary to conduct further research on the use of PRSC and MEOWS in Indonesia with a larger sample to determine sensitivity, specificity, and negative predictive value.

Due to the limited time of the study, there were differences in the number of samples in the pre-test and post-test. After conducting an evaluation in the form of FGD (Focus Group Discussion) in the intervention group, the application of the MEOWS was confirmed to be easy to accept and could be used as a permanent instrument but indeed required regular training and also required expertise in determining the decision to refer.

\section{Conclusion}

There was an increase by 1.48 times in the number of maternal referrals at the Public Health Center in Semarang after the implementation of the Maternal Early Obstetric Warning Score (MEOWS) compared to the application of PRSC. In accordance with the MEOWS score and different tests conducted on the control groups and the intervention groups, the number of maternal referrals was increased from $53.6 \%$ to $72.2 \%$ (an increase of $18.6 \%$ ). The MEOWS score was able to increase the health awareness of potential referrals. Based on the results of the study, each component of the MEOWS score was associated with possible complications in the patient.

\section{Ethical Approval}

The study was ethically approved by the Health Research Ethics Commission (KEPK) from Faculty of Medicine, Diponegoro University, Semarang/dr. Kariadi Semarang with No. 39/EC/KEPK/FKUNDIP/III/2021.

\section{Conflicts of Interest}

No conflict of interest was declared in this study

\section{Funding}

No specific funding was provided for this article.

\section{Author Contribution}

Aji Patriaji as the person in charge of study conception and design, acquisition of data, analysis and interpretation of data, drafting and writing manuscript, submission, and critical revision. Soerjo Hadijono as the person in charge of study conception and design, analysis and interpretation of data, and critical revision.

\section{Acknowledgments}

This work was supported by the Department of Obstetrics and Gynaecology, Faculty of Medicine, Diponegoro University.

\section{References}

1. Kementerian Kesehatan Republik Indonesia. Profil Kesehatan Indonesia. Jakarta: Kementerian Kesehatan RI, 2016.

2. Ramli DH, Sriatmi A, Suryoputro A. Faktorfaktor yang berhubungan dengan kinerja Gasurkes KIA dalam pendampingan ibu hamil di Kota Semarang. Jurnal Kesehatan Masyarakat. 2018:6(1):8-16.

3. Dinas Kesehatan Kota Semarang. Profil Kesehatan Semarang 2016. Semarang: Dinas Kesehatan Kota Semarang, 2016.

4. Dinas Kesehatan Provinsi Jawa Tengah. Profil Kesehatan 2017. Semarang: Dinas Kesehatan Provinsi Jawa Tengah, 2017. 
5. Kashani E, Hassanzad A, Ameri MA. The Rate of the prevalence of high-risk pregnancies and the results on pregnant mothers and the effect on parameters after the birth. Advances in Environmental Biology. 2012:6(3):1319-24.

6. Paternina-Caicedo A, Miranda J, Bourjeily G, Levinson A, Duenas C, BelloMunoz C, dkk. Kinerja Skor Peringatan Dini Obstetri pada pasien kritis untuk prediksi kematian ibu. Jurnal obstetri dan ginekologi Amerika. 2017: 216 (1): 58 e1- e8.

7. Campbell ML, Kline CR, Wiesner S, D'Alton ME, Shields LE, Friedman AM. Menerapkan Sistem Peringatan Dini Kebidanan. Laporan Jurnal Perinatologi Amerika. 2018:8(2):79-84.

8. Friedman AM. Maternal early warning systems. Obstetrics and gynecology clinics of North America. 2015;42(2):289-98.

9. Mackintosh N, Watson K, Rance S, Sandall J. Value of a modified early obstetric warning system (MEOWS) in managing maternal complications in the peripartum period: an ethnographic study. BMJ Quality \& Safety.

10. Singh A, Guleria K, Vaid NB, Jain S. Evaluation of maternal early obstetric warning system (MEOWS chart) as a predictor of obstetric morbidity: a prospective observational study. European journal of obstetrics, gynecology, and reproductive biology. 2016:207:11-7.

11. WHO. Measuring reproductive morbidity. Report of a technical working group. Geneva: World Health Organization, 1989.

12. ACOG. Severe maternal morbidity: screening and review. Am J Olster Gynecol. 2016.

13. Singh S, McGlennan A, England A, Simons R. A validation study of the CEMACH recommended modified early obstetric warning system (MEOWS). Anaesthesia. 2012;67(1):12-8.

14. Chaman RM, Yunesian M, Golestan B, Naini KH. Effect of high-risk pregnancies on infant mortality using a case - control method in a sample from rural population. Iranian journal of Epidemiology. 2007;3(4):1-6.

15. Rahmadewi, Herartri R. Faktor-faktor yang berhubungan dengan kehamilan berisiko tinggi. Gizi Indon. 2011;34(2):120-8.

16. Wanderer JP, Anderson-Dam J, Levine W, Bittner EA. Pengembangan dan validasi model prediksi intraoperatif untuk perawatan intensif pascaoperasi yang tidak direncanakan. Anestesiologi. 2013;119:516-24.

17. Creanga AA, Berg CJ, Ko JY. Maternal mortality and morbidity in the United States: where are we now? J Womens Health. 2014;23:3-9.
18. Lewis G. Saving Mothers' Lives: Reviewing maternal deaths to make motherhood safer 20032005. London: CEMACH. 2007.

19. Cole M. A modified early obstetric warning system. British Journal of Midwifery. 2014;22(12):862-8.

20. Widarta GD, Laksana MAC, Sulistyono A, Purnomo W. Deteksi dini risiko ibu hamil dengan Kartu Skor Poedji Rochjati dan pencegahan faktor empat terlambat. Majalah Obstetri \& Ginekologi. 2015:28-32.

21. Ryan HM, Jones MA, Payne BA, Sharma S, Hutfield AM, Lee $\mathrm{T}$, et al. Validating the performance of the Modified Early Obstetric Warning System multivariable model to predict maternal intensive care unit admission. JOGC. 2017:39(9):728-33.

22. Tuyishime E, Ingabire H, Mvukiyehe JP, Durieux $M$, Twagirumugabe $T$. Implementing the Risk Indentification (RI) and Modified Early Obstetric Warning Signs (MEOWS) tool in district hospital in Rwanda. a cross-sectional study. BMC Pregnancy and Childbirth. 2020. 20:268.

23. Mbchb SEE, Mba WAG, Lappen JR, Winter C, Fox R, Lenguerrand E, et al. Modified obstetric early warning scoring systems (MOEWS): validating the diagnostic performance for severe sepsis in women with chorioamnionitis. Am J Obstet Gynecol [Internet]. 2015;(November 2014). Available from: http://dx.doi.org/10.1016/j.ajog.2014.11.007.

24. Zuckerwise LC, Lipkind HS. Seminars in Perinatology Maternal early warning systems Towards reducing preventable maternal mortality and severe maternal morbidity through improved clinical surveillance and responsiveness. Semin Perinatol [Internet]. 2017;1-5. Available from: http://dx.doi.org/10.1053/j.semperi.2017.03.005.

25. Tamara Y, Luthfi M, Prawitasari S. Hubungan Maternal Early Obstetric Warning Score (MEOWS) dengan perawatan di intensive care unit pada pasien preeklamsia berat di RSUP Dr. Sardjito. Jurnal Kesehatan Reproduksi. 2019. 6:79-84.

26. Shields LE, Wiesner S, Mba RN, Klein C, Cnm RN, Pelletreau B, et al. Use of Maternal Early Warning Trigger tool reduces maternal morbidity. Am J Obstet Gynecol [Internet]. 2016;1-6. Available from: http://dx.doi.org/10.1016/j.ajog.2016.01.154.

27. Shields LE, Wiesner S, Klein C, Pelletreau B, Hedriana HL. Use of maternal early warning trigger tool reduces maternal morbidity. American journal of obstetrics and gynecology. 2016;214(4):527 e1- e6. 
Patriajati A, Hadijono $S$

Diponegoro International Medical Journal, 2021, 2 (2), 54-62

28. Umar A, Ameh C, Muriithi, Mathai M. Early warning system in obstetrics: a systematic literature review. PloS ONE 2019. 14(5):1-15 